\title{
Anti-inflammatory Effects of Deuterium-Depleted Water Plus Rosa Damascena Mill. Essential Oil Via Cyclooxygenase-2 Pathway in Rats
}

\section{Döteryumu Azaltılmış Su ve Rosa Damascena Mill. Uçucu Yağının Sıçanlarda Siklooksijenaz-2 Yolağı Üzerinden Anti-enflamatuvar Etkileri}

\author{
(D) Faezeh FATEMI ${ }^{*}$, (D) Abbas GOLBODAGH², (D) Reza HOJIHOSSEINI², (D) Abolfazl DADKHAH³, (D) Kambiz AKBARZADEH4 , (D) Salome DINI5, \\ (D) Mohammad Reza Mohammadi MALAYERI6 \\ 1Nuclear Science and Technology Research Institute, Materials and Nuclear Fuel Research School, Tehran, Iran \\ 2Payame Noor University, Faculty of Sciences, Department of Biochemistry, Tehran, Iran \\ 3Islamic Azad University, Qom Branch, Faculty of Medicine, Department of Medicine, Qom, Iran \\ ${ }^{4}$ Mashhad University of Medical Science, Faculty of Medicine, Mashhad, Iran \\ 5Islamic Azad University, Karaj Branch, Young Researchers and Elite Club, Karaj, Iran \\ 6Islamic Azad University, Garmsar Branch, Faculty of Veterinary Medicine, Department of Pathobiology, Garmsar, Iran
}

\begin{abstract}
Objectives: Natural medicine has been proposed for treating sepsis worldwide. Therefore, in this study, the effect of deuterium-depleted water (DDW) alone and adjuvant with Rosa damascena Mill. (RD) essential oils was considered through the evaluation of oxidative stress-antioxidant parameters and the expression of cyclooxygenase-2 (COX-2) inflammatory gene in liver damage caused by sepsis.

Materials and Methods: The rats were randomly divided into 5 groups: 1) laparotomy group; 2) cecal ligation and puncture (CLP) group; 3 ) DDW (15 ppm and 30 ppm doses) group; 4) DDW (15 ppm and 30 ppm doses) plus RD essential oil (100 mg/kg.bw); 5) indomethacin (2 mg/kg.bw) as a positive control. The treatments were daily administrated for 2 weeks and the CLP model was created on the day 15 . Then, the animals were killed and their liver tissue was separated for histopathologic and biochemical assessment.

Results: Our results demonstrated that the treatment of animals with DDW and DDW plus RD essential oil was effective due to the regulation of the oxidative stress-antioxidant parameters including lipid peroxidation, glutathione (GSH), GSH s-transferases, myeloperoxidase, ferric reducing ability of plasma and inflammatory parameters such as prostaglandin E2 and COX-2. Pathological studies also showed that sepsis led to the liver tissue injuries, which can be reduced by treatments.

Conclusion: Sepsis caused oxidative stress in the liver tissue, but the administration of DDW and DDW plus RD essential oil can be useful to prevent and heal these injuries.

Key words: Deuterium-depleted water, Rosa damascena Mill essential oil, cecal ligation and puncture, oxidative stress-antioxidant parameters, sepsis
\end{abstract}

öz

Amaç: Dünyada sepsis tedavisi için doğal kaynaklı ilaçlar önerilmektedir. Bu nedenle, bu çalıșmada, döteryumu azaltılmış suyun (DDW) tek başına ve Rosa damascena (RD) Mill. uçucu yağı ile birlikte etkisi oksidatif stres-antioksidan parametrelerin ve sepsisten kaynaklanan karaciğer hasarında siklooksijenaz-2 (COX-2) enflamatuvar genin ekspresyonunun değerlendirilmesi yoluyla belirlenmiștir.

Gereç ve Yöntemler: Sıçanlar rastgele 5 gruba ayrılmıştır: 1) laparotomi grubu; 2) çekal ligasyon ve punksiyon (CLP) grubu; 3 ) DDW'ler (15 ppm ve 30 ppm dozlar) grupları; 4) DDW'ler (15 ppm ve 30 ppm dozlar) ile RD (100 mg/kg); 5) pozitif bir kontrol olarak indometasin (2 mg/kg). Tedaviler günlük olarak iki hafta boyunca yapılmış ve 15. günde CLP modeli oluşturulmuştur. Daha sonra hayvanlar öldürülmüş ve karaciğer dokuları histopatolojik ve biyokimyasal değerlendirmeler için ayrılmıştır.

*Correspondence: E-mail: fatemi81@yahoo.com, Phone: +989124186349 ORCID-ID: orcid.org/0000-0002-1092-9038

Received: 15.09.2018, Accepted: 15.11.2018

OTurk J Pharm Sci, Published by Galenos Publishing House. 
Bulgular: Sonuçlarımız, DDW ve DDW ile RD uygulamalarının, hayvanların lipid peroksidasyon, glutatyon (GSH), GSH s-transferaz, miyeloperoksidaz, plazma demir indirgeme kabiliyeti dahil olmak üzere oksidatif stres-antioksidan parametrelerinin; prostaglandin E2 ve COX-2 gibi enflamatuvar parametrelerinin düzenlenmesinden dolayı etkili olduğunu göstermiştir. Patolojik çalışmalar da sepsisin karaciğer doku yaralanmalarına yol açtığını ve söz konusu uygulamalarla azaltılabileceğini göstermiştir.

Sonuç: Sepsis karaciğer dokusunda oksidatif strese neden olmuştur, ancak DDW ve DDW ile RD'nin birlikte uygulanması bu hasarı önlemek ve iyileștirmek için yararlı olabilir.

Anahtar kelimeler: Döteryumu azaltılmış su, Rosa damascena Mill, uçucu yağ, çekal ligasyon ve punksiyon, oksidatif stres-antioksidan parametreler, sepsis

\section{INTRODUCTION}

Natural products are increasingly becoming one of the most important resources for replacing chemical compounds. They will undergo continual use toward meeting the urgent need to develop effective drugs, and they will play a leading role in the discovery of drugs for treating human diseases, especially chronic disorders.

Deuterium-depleted water (DDW), known as light water, has a lower concentration of naturally occurring deuterium (20$25 \mathrm{ppm}$ vs. $150 \mathrm{ppm})^{2}$ The use of DDW for a long period may reduce the concentration of deuterium in the liquids and tissues of organisms due to isotopic exchange reactions. These reactions may impact the cellular cycle and cell proliferation.,3.4 Previous studies stated that a decreased amount of deuterium in drinking water caused different biological activities such as anticancer, antioxidant, and chemopreventive properties. ${ }^{5-8}$

On the other hand, our recent study reported that Rosa damascena Mill. (RD) essential oils with the main chemical compositions of citranellol (66.11\%), transgeraniol (11.56\%), and phenylethyl alcohol (5.33\%) had antioxidant and anti-inflammatory effects in a sepsis model. ${ }^{9}$ RD essential oil, belonging to the family Roseaceae, ${ }^{10}$ is one of the most valuable sources of flavors and fragrances worldwide and has some applications in the medicine and food industries."

A study showed that RD essential oil has beneficial effects in the treatment of various disorders, e.g., inflammatory reactions, premenstrual breast tenderness, and spasms. ${ }^{12}$ It is traditionally used for the treatment of abdominal and chest pain and depression. ${ }^{13}$ Several biological activities of RD essential oil have also been reported, including analgesic, antitussive, antidepressant, antispasmodic, antioxidant, and anti-HIV activities. ${ }^{14-17}$ A study showed that the oil extracted from RD essential oil exhibited antimicrobial activity against a large number of microorganisms, especially against Proteus vulgaris and Klebsiella pneumoniae.18

Regarding the beneficial therapeutic properties of these natural products, their probable anti-inflammatory and antioxidant effects in treating severe diseases such as sepsis should be considered.

Sepsis is a systemic body reaction to invasive microorganisms like bacteria and fungi. It is one of the top ten main causes of death among all patients admitted to hospital. It causes inflammation, microvascular damage, and coagulopathy, hemodynamic instability, multiple organ dysfunction, and immunosuppression. It is an important medical problem all over the world and is the most common cause of death among critically ill patients. ${ }^{19,20}$ The cecal ligation and puncture (CLP) model as a stable, repetitive, and applicable model leads to the pollution of the abdominal cavity by bacteria-carrying intestinal contents and induces a wide range of systemic inflammatory responses leading to sepsis. ${ }^{21,22}$ In the CLP model, bacteria spreading from infection sites and entering the bloodstream are rapidly trapped in many organs, such as the liver, kidney, lung, and spleen, and bound to the surface of specific target cells and macrophages in the target organ and subsequently killed by infiltrating neutrophils. ${ }^{23,24}$ The organs are damaged in mice with lethal sepsis induced by CLP and also in humans with sepsis. This injury is mainly associated with ineffective bacterial clearance, leading to bacterial dissemination and high mortality rates. ${ }^{24}$ Several reports have demonstrated that inflammatory cytokines can serve as both makers and mediators of the severity of sepsis and elevated levels of these cytokines predict mortality following CLP. ${ }^{25-27}$

Regarding the increase in resistance to and side effects of antibiotics and synthetic drugs in sepsis treatment, natural products with high antibacterial and antioxidant capacities could be a suitable alternative. In the current study, inflammation was induced by a CLP inflammatory model in rats in order to consider the preventive anti-inflammatory effects of DDW alone and concomitant with RD through the estimation of cyclooxygenase-2 (COX-2) gene expression and prostaglandin E2 (PGE2) as well as the assessment of oxidative stress-antioxidant parameters such as glutathione (GSH), lipid peroxidation (LP), GSH s-transferases (GST), myeloperoxidase (MPO), and ferric reducing ability of plasma (FRAP).

\section{MATERIALS AND METHODS}

\section{Plant materials and DDW preparations}

DDW (15 and $30 \mathrm{ppm}$ ) obtained from the Atomic Energy Organization of Iran was used in our study. In addition, the essential oils of RD were obtained from Barij Essence Pharmaceutical Co, Kashan Iran (Batch No: 714043, Sample Serial No: AE932009).

\section{Animals}

The study was carried out on 70 male Wistar rats (200-250 $\mathrm{g}$ ). The rats were kept under standard conditions (12 h light/12 $\mathrm{h}$ dark) at $20-25^{\circ} \mathrm{C}$ for 2 weeks. The animal studies had been approved by the Medical Ethics Committee of Tarbiat Modares 
University based on the World Medical Association Declaration of Helsinki. The CLP model was used to cause sepsis in rats. ${ }^{9}$

The rats (10 rats in each group) were randomly divided into 7 groups: 1) laparotomy (LAP) group (LAP) as a negative control group; 2) CLP group as a control group; 3) DDW: the rats received DDW orally (at a dose of $15 \mathrm{ppm}$ and $30 \mathrm{ppm}$ ) for 2 weeks; 4) DDW+RD: the rats received RD essential oil at 100 $\mathrm{mg} / \mathrm{kg}$.bw dose plus DDW 15 ppm and 30 ppm for 2 weeks; 5) indomethacin: the rats received $2 \mathrm{mg} / \mathrm{kg}$.bw indomethacin orally, serving as a positive control group. After 15 days, CLP surgery was performed in all groups.

Next, $24 \mathrm{~h}$ after CLP surgery, the rats were anesthetized and heparinated blood samples were collected by heart puncture from all the animals and centrifuged at $3000 \times \mathrm{g}$ for $10 \mathrm{~min}$ to obtain the plasma. Then the rats were killed and their livers were removed and processed for histological and biochemical assays.

\section{Assessment of PGE2}

Plasma PGE2 level was measured by enzyme-linked immunosorbent assay kit (ELISA Kit; BioAssay System) according to the producer's instructions.

\section{Assessment of COX-2 gene expression}

Total RNA from liver tissues was prepared with an RNA total kit (BioBasic Inc, Canada). cDNA was synthesized with a PrimeScript ${ }^{\mathrm{TM}}$ RT reagent kit (Takara Bio Inc, Japan) and oligo dt primers (Takara Bio Inc, Japan), according to the manufacturer's protocol.

Then the primers for PCR were designed with the Gene Runner software version 3.05 and primer 3 servers (COX2 forward: 5'ACCTCTGCGATGCTCTTC3'; COX-2 reverse: 5' AGGAATCTCGGCGTAGTAC3'; Glyceraldehyde 3-phosphate dehydrogenase (GAPDH) forward: 5' TGCCAGCCTCGTCTCATAG 3'; GAPDH reverse: 5"ACTGTGCCGTTGAACTTGC 3'). Blast N searches were used to check primer specificity. The cDNA samples were amplified by PCR amplification and then checked by $2.5 \%$ agarose gel electrophoresis to ensure whether the PCRs contained a product with the expected size.

The relative expression of the selected gene was measured with a real-time PCR system (Rotor-Gene Q, QIAGEN). The reaction mixture contained $5 \mu \mathrm{L}$ of SYBR Green real-time PCR Master Mix (QIAGEN), which includes Taq DNA polymerase, dNTP, $\mathrm{MgCl}_{2}$, and SYBR Green I dye, $0.2 \mu \mathrm{L}$ of a $10 \mathrm{mM}$ solution of sense-anti-sense primer, $0.5 \mu \mathrm{L}$ of template cDNA added with $\mathrm{H}_{2} \mathrm{O}$ to a total of $10 \mu \mathrm{L}$. The negative controls were also designed as above but without cDNA. The thermal cycling conditions consisted of an initial denaturation stage at $95^{\circ} \mathrm{C}$ for $2 \mathrm{~min}$, followed by 40 cycles at $95^{\circ} \mathrm{C}$ for $15 \mathrm{~s}, 60^{\circ} \mathrm{C}$ for $20 \mathrm{~s}$, and $72^{\circ} \mathrm{C}$ for $20 \mathrm{~s}$. At the completion of each run, melting curves for the amplicons were measured by raising the temperature by $0.3^{\circ} \mathrm{C}$ from 57 to $95^{\circ} \mathrm{C}$ while monitoring fluorescence. All expression data were normalized using GAPDH expression as the internal standard.

\section{Assessment of antioxidant and liver parameters}

\section{GSH test}

It was estimated in liver homogenates according to the procedure reported by Seldak and Lindsay. ${ }^{28} \mathrm{~A}$ weighed portion of the liver was homogenized in ethylenediaminetetraacetic acid (EDTA) $(0.02 \mathrm{M})$. Then $5 \mathrm{~mL}$ of homogenate was immediately precipitated with $1 \mathrm{~mL}$ of $50 \%$ trichloroacetic acid and $4 \mathrm{~mL}$ of distilled water; the precipitate was removed after centrifugation at $3000 \times \mathrm{g}$ for $15 \mathrm{~min}$. To determine the GSH level, $2 \mathrm{~mL}$ of supernatant was mixed with $4 \mathrm{~mL}$ of tris buffer $(0.4 \mathrm{M})$, containing EDTA $(0.2 \mathrm{M})$ and $0.1 \mathrm{~mL}$ of $5,5^{\prime}$-dithiobis (2-nitrobenzoic acid) $(0.01 \mathrm{M})$. Absorbance was measured at $412 \mathrm{~nm}$ using a spectrophotometer.

LP test

The concentration of thiobarbituric acid reactive substances as an indicator for LP production was measured spectrophotometrically using thiobarbituric acid reagent based on the procedure described by Buege and Aust. ${ }^{29}$

\section{GST test}

GST was measured spectrophotometrically using 1-chloro-2, 4-dinitrobenzene (a general substrate) according to the procedures described by Habig et al. ${ }^{30}$

\section{FRAP test}

FRAP was performed using 2,4,6-Tris (2-pyridyl)-s-triazine reagent as described by Benzie and Strain. ${ }^{31}$ FRAP level was calculated by plotting a standard curve of absorbance against $\mu \mathrm{mol} / \mathrm{L}$ concentration of Fe (2) standard solution.

\section{MPO test}

MPO activity was measured, with minor modification, according to the procedure reported by Hillegass et al. ${ }^{32}$

\section{Assessment of liver enzymes}

To confirm the liver function and injury, serum alanine transaminase (ALT), aspartate transaminase (AST) (Pars Azmoon, Co, Iran), alkaline phosphatase (ALP) (Ziest Chem Diagnostics Co, Iran), and total bilirubin (BILI) (Darman Faraz Kave Co, Iran) were determined spectrophotometrically according to the procedure described in the kit purchased.

\section{Histological analysis}

Liver biopsies were collected from all the control and treated animals $24 \mathrm{~h}$ after sepsis induction. The tissue samples were fixed in $10 \%$ phosphate-buffered saline of formaldehyde solution. Dehydration was performed in graded ethanol, followed by embedding in paraffin, and a $5-\mu m$ section was stained with hematoxylin and eosin. For histopathological analysis, the sections were examined by light microscopy (Olympus CX31RBSF). The histological changes were quantitatively and semiquantitatively analyzed by a veterinary pathologist. The histologic index was scored from 0 (minimal) to 4 (maximal); score $0=$ from 0 to 9 neutrophils, score $1=$ from 10 to 19 neutrophils, score $2=$ from 20 to 29 neutrophils, score $3=$ from 30 to 39 neutrophils, score $4=$ more than 40 neutrophils. The scoring system included: zero ( 0 ) for normal condition, 1+ for 
mild changes, 2+ for average changes, 3+ for severe changes, and $4+$ score for more severe changes.

\section{Statistical analysis}

The data was analyzed with Statistical Package for the Social Sciences v.19. The data was expressed as mean \pm standard error. One-way analysis of variance was applied to compare the mean values. The normal distribution of the data was examined by Kolmogorov-Smirnov normality test. A p-value of less than 0.05 was considered statistically significant.

\section{RESULTS}

\section{Effect of DDW and DDW plus RD essential oil on PGE2 and COX-2 in sepsis}

The results indicated that the level of PGE2 value increased as evidenced by the significant rise $(p<0.05)$ in the level of COX-2 in the CLP group. However, the administration of DDW reduced considerably $(p<0.05)$ the level of COX-2 compared to the CLP group. Indeed, the PGE2 level returned significantly ( $p<0.05)$ to normal levels after using DDW plus RD essential oil ( $p<0.05)$ but there was no significant change $(p>0.05)$ in COX-2 gene expression. Likewise, indomethacin as a positive control decreased significantly ( $p<0.05$ ) the levels of PGE2 and COX-2 gene expression when compared to the CLP group (Table 1).

Effect of DDW and DDW plus RD essential oil on oxidative stress-antioxidant parameters in sepsis

As shown in Table 2, the levels of LP and MPO significantly ( $p<0.05)$ increased in the CLP group, while the level of FRAP went down remarkably ( $p<0.05)$. Moreover, sepsis led to a significant decrease in the liver GSH as compared to the LAP group ( $p<0.05$ ). The DDW and DDW plus RD essential oil restored the levels of LP, MPO, and GSH in comparison to the CLP group. However, the administration of DDW plus RD essential oil returned the level of FRAP to the normal one ( $p>0.05)$. Meanwhile, administration of indomethacin to rats showed the same results in the treatment groups ( $p<0.05)$, whereas GST level did not show any significant changes ( $p>0.05$ ) in the groups even after using indomethacin as a positive control (Table 2).

Table 1. The effect of DDW and DDW + RD on PGE2 and COX-2 gene expression in septic rats

\begin{tabular}{lll} 
Groups & PGE2 $(\mathrm{ng} / \mathrm{mL})$ & $\begin{array}{l}\text { COX-2 gene } \\
\text { expression }\end{array}$ \\
\hline LAP & $508 \pm 26.7$ & $0 \pm 0.03$ \\
\hline CLP & $796 \pm 20.7^{\mathrm{a}}$ & $0.43 \pm 0.05^{\mathrm{a}}$ \\
\hline DDW15 & $584 \pm 18.4^{\mathrm{b}}$ & $0.32 \pm 0.03^{\mathrm{b}}$ \\
\hline DDW30 & $709 \pm 18^{\mathrm{b}}$ & $0.23 \pm 0.02^{\mathrm{b}}$ \\
\hline RD100+DDW15 & $486 \pm 24.6^{\mathrm{b}}$ & $0.48 \pm 0.05$ \\
\hline RD100+DDW30 & $530 \pm 17.4^{\mathrm{b}}$ & $0.45 \pm 0.05$ \\
\hline Indomethacin & $536 \pm 32.8^{\mathrm{b}}$ & $0.15 \pm 0.11^{\mathrm{b}}$ \\
\hline
\end{tabular}

${ }^{a} p<0.05$ is considered significant between LAP and CLP group, ${ }^{b} p<0.05$ is considered significant between CLP and treatment groups, DDW: Deuterium-depleted water, RD: Rosa damascena Mill, PGE2: Prostaglandin E2, COX-2: cyclooxygenase-2, LAP: Laparotomy, CLP: Cecal ligation and puncture
Effect of DDW and DDW plus RD on liver enzymes in sepsis

The levels of AST and ALT significantly increased ( $p<0.05$ ) as compared to the LAP group (Table 3 ). In contrast, the rats pretreated with DDW and DDW plus RD essential oil surprisingly ( $p<0.05$ ) had restored AST and ALT levels as compared to the CLP group. Similarly, indomethacin ( $2 \mathrm{mg} / \mathrm{kg} . \mathrm{bw}$ ) as a positive control returned the levels of AST and ALT to normal levels ( $p<0.05$ ) (Table 2), whereas the levels of ALP and BILI had no remarkable changes in all groups even after using DDW and DDW plus RD essential oil (Table 3).

\section{Histological findings}

There were some mild changes in the hepatocytes in the LAP group (Figure 1A), whereas severe congestion, interstitial edema, and margination of neutrophils in the venules and sinusoids were observed in the CLP group. Neutrophils and mononuclear cells were also infiltrated in the portal tracts and sinusoids in the septic group. Kupffer cell hyperplasia and granular degeneration were seen in the CLP group. There were no signs of necrosis in the hepatocytes. All the changes in the CLP group revealed a kind of hepatitis called nonspecific reactive hepatitis (Figures $1 \mathrm{~B} 1$ and $\mathrm{B} 2$ ). The treated groups showed improved histopathological lesions except for the DDW30 plus RD essential oil treated group. The portal tract and the parenchyma were nearly in normal condition in the DDW15 and DDW30 treated groups (Figures $1 \mathrm{C}$ and D). Moreover, the presence of a few neutrophils in the sinusoids of the DDW15 plus RD essential oil treated group was observed (Figure 1E). However, there were neutrophil infiltrations in the sinusoids in the DDW30 plus RD essential oil treated group. Kupffer cells that show hypertrophy and hyperplasia were also obvious in this group (Figure 1F). Furthermore, in the indomethacin group, reduced amounts of neutrophils were seen (Figure 1G).

As shown in Table 4, the CLP group obviously showed neutrophil margination and infiltration, mononuclear cell infiltration, and Kupffer cell hyperplasia as compared with the LAP group $(p \leq 0.05)$. Concerning portal inflammation, it was also meaningful in the CLP group in comparison with the LAP group ( $p \leq 0.05$ ). However, there were no obvious differences regarding granular degeneration or inflammatory foci between the study groups ( $p>0.05$ ). All the treatment groups, except the RD+DDW30 treated group, had prominently reduced neutrophil margination and infiltration, mononuclear cells infiltration, Kupffer cell hyperplasia, and portal inflammation in comparison with the CLP group ( $p \leq 0.05)$.

\section{DISCUSSION}

Our previous results demonstrated that medicinal plants with bioactive constituents such as RD essential oil as well as Berberis integerrima and Ferula assafoetida extracts significantly affect oxidative stress-antioxidant parameters and detoxifying enzymes as well as COX-2 gene expression. 9, 33,34 There is also evidence indicating hepatoprotective activity of DDW against acetaminophen. ${ }^{7}$ Following this, the present study was designed 
to consider, for the first time, the therapeutic efficacy of DDW and DDW plus RD essential oil against liver injury induced by CLP in septic rats.

Our results revealed that the sepsis induced by CLP significantly increased ( $p<0.05$ ) the levels of LP and MPO along with PGE2 level and COX-2 expression. Likewise, the levels of AST and
ALT activities went up sharply due to CLP surgery compared with the LAP group (Table 3), while there was a considerable decrease in the amount of GSH and FRAP (as an important factor in the oxidative stress-antioxidant balance) in comparison with the LAP group (Tables 1 and 2; Figure 1).

Sepsis reflects a systemic inflammatory syndrome in response to an infection and represents the leading cause of death in the

\begin{tabular}{|c|c|c|c|c|c|}
\hline Groups & LP (pmol/mg protein) & $\begin{array}{l}\text { GSH (nmol/mg } \\
\text { protein) }\end{array}$ & $\begin{array}{l}\text { MPO }(U / \mathrm{mg} \\
\text { protein) }\end{array}$ & $\begin{array}{l}\text { GST }(\mathrm{nmol} / \mathrm{min} / \mathrm{mg} \\
\text { protein) }\end{array}$ & $\operatorname{FRAP}(\mu \mathrm{mol} / \mathrm{L})$ \\
\hline CLP & $18.51 \pm 1.53^{a}$ & $7.28 \pm 0.67^{\mathrm{a}}$ & $26.13 \pm 0.7^{\mathrm{a}}$ & $1173 \pm 32.11$ & $257 \pm 10.98^{a}$ \\
\hline DDW15 & $11.95 \pm 1^{b}$ & $9.86 \pm 0.75^{b}$ & $18.9 \pm 0.98^{b}$ & $1355 \pm 46.02$ & $265 \pm 15.54$ \\
\hline RD+DDW15 & $10.23 \pm 0.908^{b}$ & $13.9 \pm 1.03^{b}$ & $10.34 \pm 0.75^{b}$ & $1976 \pm 66.67$ & $374 \pm 7.33^{\mathrm{b}}$ \\
\hline RD+DDW30 & $11.15 \pm 0.86^{b}$ & $14.25 \pm 1^{\mathrm{b}}$ & $11.24 \pm 0.8^{b}$ & $1878 \pm 45.09$ & $383 \pm 6.2^{b}$ \\
\hline Indomethacin & $11.8 \pm 0.87^{b}$ & $11.26 \pm 0.95^{b}$ & $6.58 \pm 0.2^{b}$ & $1076 \pm 48.22$ & $280 \pm 18.2^{b}$ \\
\hline
\end{tabular}

${ }^{a} p<0.05$ is considered significantly between LAP and CLP groups, ${ }^{b} p<0.05$ is considered significantly between CLP and treatment groups, DDW: Deuterium-depleted water, RD: Rosa damascena Mill, LAP: Laparotomy, CLP: Cecal ligation and puncture, LP: Lipid peroxidation, GSH: Glutathione, MPO: Myeloperoxidase, FRAP: Ferric reducing ability of plasma, GST: Glutathione s-transferases

\section{Table 3. The effect of DDW and DDW+RD the on liver enzymes in septic rats}

\begin{tabular}{lllll} 
Groups & AST $(\mathrm{U} / \mathrm{L})$ & ALT $(\mathrm{U} / \mathrm{L})$ & ALP $(\mathrm{U} / \mathrm{L})$ & $\mathrm{BILI}(\mathrm{mg} / \mathrm{dL})$ \\
\hline LAP & $132 \pm 9.58$ & $61 \pm 5.35$ & $364 \pm 33.8$ & $0.54 \pm 0.05$ \\
\hline CLP & $317 \pm 13.58^{\mathrm{a}}$ & $136 \pm 8.76^{\mathrm{a}}$ & $400 \pm 25.8$ & $0.6 \pm 0.05$ \\
\hline DDW15 & $168 \pm 11.76^{\mathrm{b}}$ & $74 \pm 7.63^{\mathrm{b}}$ & $394 \pm 33$ & $0.59 \pm 0.04$ \\
\hline DDW30 & $171 \pm 9.91^{\mathrm{b}}$ & $78 \pm 8.01^{\mathrm{b}}$ & $377 \pm 30.8$ & $0.58 \pm 0.04$ \\
\hline RD+DDW15 & $135 \pm 7.92^{\mathrm{b}}$ & $64 \pm 5.93^{\mathrm{b}}$ & $357 \pm 27.4$ & $0.55 \pm 0.04$ \\
\hline RD+DDW30 & $143 \pm 10.06^{\mathrm{b}}$ & $67 \pm 6.65^{\mathrm{b}}$ & $368 \pm 20.5$ & $0.55 \pm 0.04$ \\
\hline Indomethacin & $150 \pm 11.72^{\mathrm{b}}$ & $73 \pm 4.48^{\mathrm{b}}$ & $371 \pm 30$ & $0.54 \pm 0.04$
\end{tabular}

${ }^{a} \mathrm{p}<0.05$ is considered significantly between LAP and CLP groups, ${ }^{b} \mathrm{p}<0.05$ is considered significantly between CLP and treatment groups, DDW: Deuterium-depleted water, RD: Rosa damascena Mill, LAP: Laparotomy, CLP: Cecal ligation and puncture, AST: Aspartate transaminase, ALT: Alanine transaminase, BILI: Bilirubin, ALP: Alkaline phosphatase

\section{Table 4. Mean values and standard error of histopathologic variables of the liver specimens in the study groups}

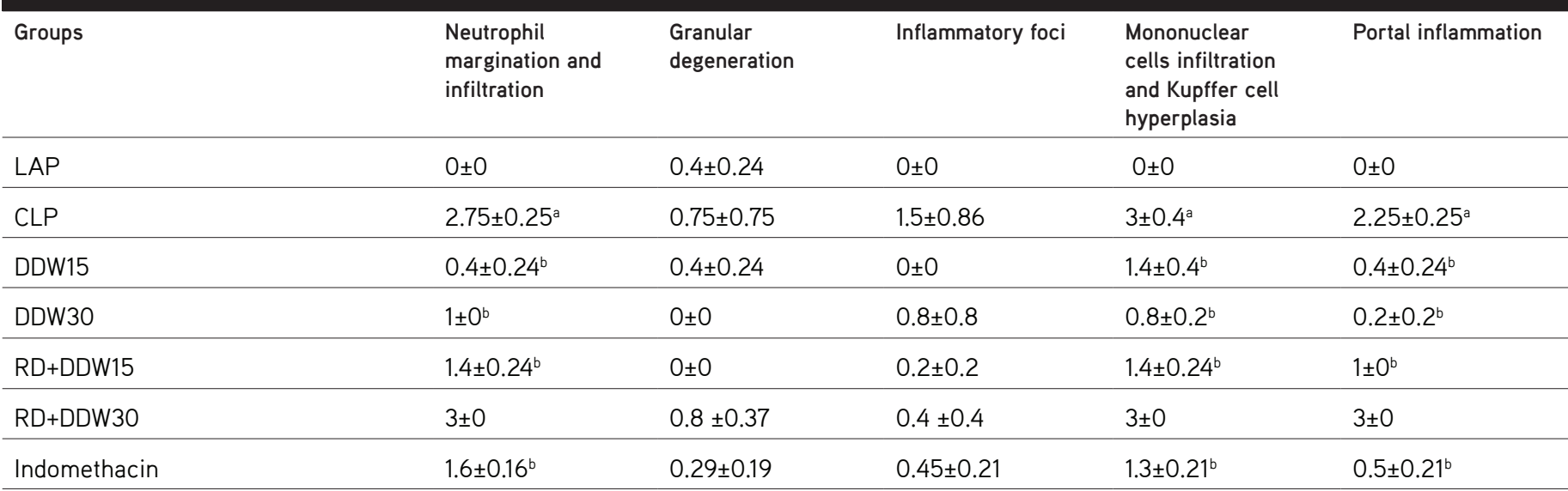

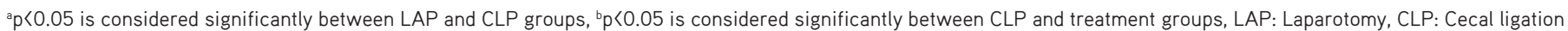
and puncture, DDW: Deuterium-depleted water, RD: Rosa damascena Mill 
intensive care unit. During the process of sepsis, the liver plays an important role in defensive responses to scavenge bacteria and produce an inflammatory mediator. ${ }^{35}$ Recent studies have also observed that liver dysfunction is an early event in sepsis. ${ }^{36}$ The hepatocellular liver enzymes AST and ALT have been regarded as markers of liver injury. ${ }^{37}$
Our results (Table 3 ) clearly showed that sepsis increased liver enzymes such as AST and ALT caused by liver damage. The biochemical results along with the histological findings (Figure 1) confirmed the pathophysiological changes in liver function damaged by sepsis. Other studies also proved that there is a direct link between the oxidative stress conditions and organ
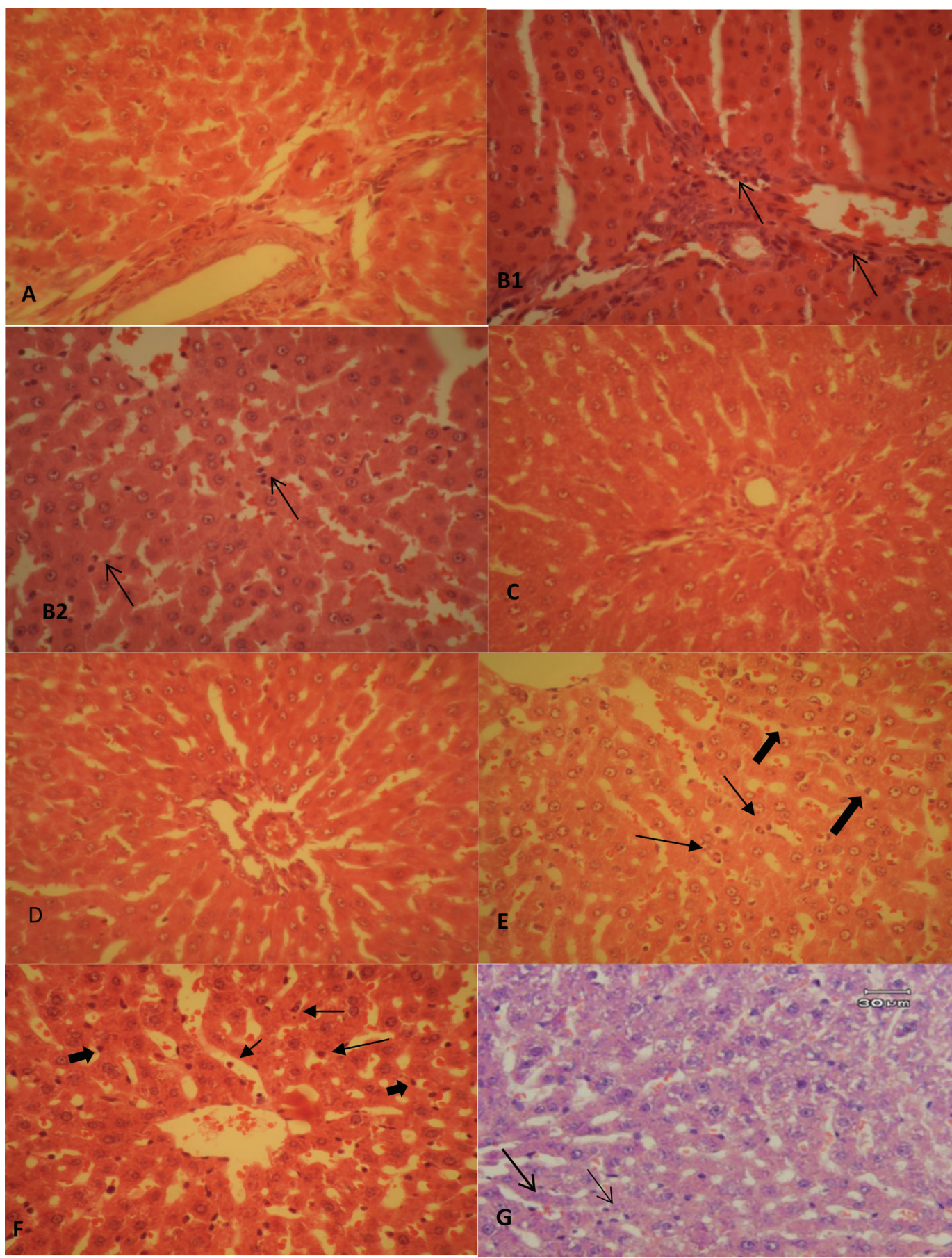

Figure 1. Histopathological studies. A) LAP group, the portal tract and the hepatocytes in normal condition. B1) CLP group, neutrophil infiltration in the portal tract (arrows). B2) CLP group, neutrophil infiltration in the sinusoids that can be seen easily with their dark nuclei (arrows). C) DDW15 group, the portal tract and the parenchyma in normal condition. $\mathrm{H}$ and $\mathrm{E}, 400 x$. D) DDW30 group, the portal tract and the parenchyma in normal condition. $\mathrm{H}$ and $\mathrm{E}$, 400x. E) DDW15+RD, presence of a few neutrophils in the sinusoids (thin arrows). Kupffer cells can also be seen in the picture (thick arrows). $\mathrm{H}$ and $\mathrm{E}, 400 \times \mathrm{F}$ ) DDW30+RD group, neutrophil infiltration in the sinusoids (thin arrows). Kupffer cells showing hypertrophy and hyperplasia are also obvious (thick arrows). $H$ and $E, 400 x . G$ ) Indomethacin group, a few infiltrated neutrophils (arrows) can be seen. $\mathrm{H}$ and $\mathrm{E}, 400 \times$ 
injuries in the CLP model. ${ }^{38,39}$ In addition, initiation of oxidative stress was identified by the increase in malondialdehyde level. ${ }^{40} \mathrm{GSH}$ also plays a principal role in protecting cells from oxidative damage..$^{41}$ Therefore, the fall in GSH level in the liver in the septic groups and the rise in LP demonstrated that sepsis promoted destruction in balancing antioxidants and oxidative stress. While MPO is a protein in neutrophils that participates in the early inflammatory process in patients with sepsis, ${ }^{42,43}$ its elevation in septic animals concomitant with LP production led to hepatic dysfunction.

Furthermore, COX-2 as an early expressed gene is not only detected in most normal tissues, but it is also induced by stimuli such as pro-inflammatory cytokines, ${ }^{44}$ leading to PGE2 production, which acts on neurons and contributes to the systemic responses to inflammation. ${ }^{45}$ In our study, an increase in the level of COX-2 expression was detected in septic rats as well as PGE2 concentration in plasma level compared to the control group (Table 1).

Regarding the importance of treatment of sepsis, studies confirmed the main role of antioxidants in reducing the tissue damage due to scavenging free radicals. ${ }^{9,46-48}$ To confirm, our results demonstrated that the administration of DDW and DDW plus RD essential oil was effective in sepsis treatment, where the levels of LP, MPO, and GSH returned to the normal levels. Moreover, these treatments significantly ( $p<0.05$ ) protected the liver (based on histological analysis) and decreased the AST and ALT levels as compared to the CLP group. The PGE2 level also fell considerably $(p<0.05)$ after using DDW alone and the combination of DDW with RD. The COX-2 gene expression diminished when the rats were treated with only DDW, while there were no considerable changes in the DDW plus RD essential oil groups, which may be due to the transient state of expression of some genes in sepsis. In fact, the natural agents (DDW and DDW+RD) protect the liver from injuries in a sepsis model as potently as indomethacin, a nonsteroidal antiinflammatory drug, used clinically for its anti-inflammatory, antipyretic, and analgesic properties (Tables 2 and 3; Figure 1).

The reduction in deuterium content in the body's liquids due to isotope metabolism reactions is the main effect of DDW as light water. The decrease in this element's concentration in erythrocytes, in blood plasma, and in homogenates of laboratory animals' hearts can be achieved with the use of water with low deuterium content. Such changes induce in turn the recovery of prooxidant-antioxidant system balance and a decrease in prooxidant load in organisms, which is further accompanied by higher immunity of laboratory animals. ${ }^{49}$, 50 One study reported that DDW with its antioxidant property was effective in protecting the liver against acetaminophen toxicity. ${ }^{51}$ We demonstrated that DDW alone and in combination with Satureja rechingeri essential oil had synergistic effects in prevention of acetaminophen-induced hepatotoxicity in rats due to the reduction in oxidative stresses. ${ }^{7}$ Other research reported that the DDW pretreatment protected the liver from chromium toxicity by restoring the levels of AST and ALT activities. ${ }^{51}$ Furthermore, DDW has an anticancer action due to the influence on gene expression regulation and consequently on protein biosynthesis. ${ }^{52}$

Moreover, the protective effects of the oils may be due to the antioxidant activity and free radical scavenging effects of phenolic compounds and flavonoids present in them. Our current study indicated the in vivo anti-inflammatory activities of RD essential oils may be associated with their antioxidant compounds, namely citronellol, trans-geraniol and phenylethyl alcohol as the main constituents of the essential oils, which exhibited antioxidant activities by 2,2-difenil-1pikrilhidrazil and $\beta$-carotene-linoleic acid bleaching assays. ${ }^{9} \mathrm{~A}$ previous study also revealed that the essential oil of rosemary containing antioxidant compounds has strong antioxidant and hepatoprotective activities by modulating the malondialdehyde and GSH levels and also catalase, peroxidase, GSH peroxidase, and GSH reductase activities. That study showed that hepatoprotective activity can be attributed to 1,8-cineole as its major compound as well. ${ }^{53}$ Nithianantham et al. ${ }^{54}$ also reported that the hepatoprotective activity of Clitoria ternatea leaf may be due to its free radical-scavenging and antioxidant activity. One study reported that the treatment of rats with ethyl acetate extracted from Asparagus cochinchinensis root suppressed inflammatory responses through inhibition of NO, COX-2, and reactive oxygen species production. ${ }^{55}$

\section{CONCLUSION}

The current findings indicated that the pretreatment of rats with DDW and DDW plus RD essential oil exerted beneficial effects on the prevention of liver damage, induced by a CLP inflammatory model, through not only reducing the levels of liver enzymes and oxidative stress-antioxidant parameters, but also through the balance of COX-2 and PGE2 levels. The histopathological studies proved that the hepatic injuries were improved via the administration of DDW and DDW plus RD essential oil as well.

Conflicts of interest: No conflict of interest was declared by the authors.

\section{REFERENCES}

1. Galm U, Shen B. Natural product drug discovery: The times have never been better. Chem Biol. 2007;14:1098-1104.

2. Rehakova R, Klimentova J, Cebova M, Barta A, Matuskova Z, Labas P, Pechanova O. Effect of deuterium-depleted water on selected cardiometabolic parameters in fructose-treated rats. Physiol Res. 2016;65(Supll 3):401.

3. Bykov MI, Dzhimak SS, Basov AA, Arcybasheva OM, Shashkov $D$, Baryshev MG. Comparative characteristics of the isotopic $D / H$ composition and antioxidant activity of freshly squeezed juices from fruits and vegetables grown in different geographical regions. Vopr Pitan. 2015;84:89-96.

4. Sergeevich DS, Alexandrovich BA, Anatolyevna EA, Viacheslavovna $\mathrm{FL}$, Alexandrovna KE, Romanovna VE, Mikhailovna LO, Gennadievich BM. Influence of Deuterium-Depleted Water on Hepatorenal Toxicity. Jundishapur J Nat Pharm Prod. 2018. 
5. Olariu L, Petcu M, Tulcan C, Buiga-Chis I, Pup M, Florin M, Brudiu I. Deuterium depleted water-antioxidant or prooxidant. Scientific Papers Veterinary Medicine. 2007;15:265-269.

6. Somlyai G, Molnár M, Laskay G, Szabó M, Berkényi T, Guller I, Kovács A. Biological significance of naturally occurring deuterium: the antitumor effect of deuterium depletion. Orv Hetil. 2010;151:1455-1460.

7. Rasooli A, Fatemi F, Akbarzadeh K, Dini S, Bahremand S. Synergistic Protective Activity of Deuterium Depleted Water (DDW) and Satureja rechingeri Essential Oil on Hepatic Oxidative Injuries Induced by Acetaminophen in Rats. Journal of Essential Oil Bearing Plants. 2016;19:1086-1101.

8. Fatemi F, Dadkhah A, Akbarzadeh K, Dini S, Hatami S, Rasooli A. Hepatoprotective Effects of Deuterium Depleted Water (DDW) Adjuvant with Satureja rechingeri Essential Oils. Electronic Journal of Biology. 2015;11:23-32.

9. Dadkhah A, Fatemi F, Mohammadi Malayeri MR, Karvin Ashtiyani MH, Noureini SK, Rasooli A. Considering the effect of Rosa Damascena essential oil on oxidative stress and COX-2 gene expression in liver of septic rats. Turk J Pharm Sci. 2019;16(4):16-24.

10. Pellati F, Orlandini G, van Leeuwen KA, Anesin G, Bertelli D, Paolini M, Benvenuti S, Camin F. Gas chromatography combined with mass spectrometry, flame ionization detection and elemental analyzer/ isotope ratio mass spectrometry for characterizing and detecting the authenticity of commercial essential oils of Rosa damascena Mill. Rapid Commun Mass Spectrom. 2013;27:591-602.

11. Shafei MN, Saberi Z, Amini S. Pharmacological effects of Rosa damascena. Iran J Basic Med Sci. 2011;14:295-307.

12. Kaul VK, Singh V, Singh B. Damask rose and marigold: prospective industrial crops. Int J Med Arom Plants. 2000:313-318.

13. Shakeri F, Boskabady MH. A review of the relaxant effect of various medicinal plants on tracheal smooth muscle, their possible mechanism(s) and potency. J Ethnopharmacol. 2015;175:528-548.

14. Mahmood N, Piacente S, Pizza C, Burke A, Khan Al, Hay AJ. The antiHIV activity and mechanisms of action of pure compounds isolated from Rosa damascena. Biochem Biophys Res Commun. 1996;229:73-79.

15. Achuthan CR, Babu BH, Padikkala J. Antioxidant and hepatoprotective effects of Rosa damascena. J Padikkala Pharm Biol. 2003;41:357-361.

16. Özkan G, Sagdic O, Baydar NG. Antioxidant and antibacterial activities of Rosa damascena flower extracts. Food Sc Technol Int. 2004;10:277281.

17. Nunes HS, Miguel MG. Rosa damascena essential oils: a brief review about chemical composition and biological properties. Trends Phytochem Res. 2017;1:111-128.

18. Mahboubi M, Kazempour N, Khamechian T, Fallah MH, Kermani MM. Chemical Composition and Antimicrobial Activity of Rosa damascena Mill. Essential Oil. Journal of Biologically Products from Nature. 2011;1:19-26.

19. Seymour CW, Liu VX, Iwashyna TJ, Brunkhorst FM, Rea TD, Scherag A, Rubenfeld G, Kahn JM, Shankar-Hari M, Singer M, Deutschman CS, Escobar GJ, Angus DC. Assessment of clinical criteria for sepsis: for the Third International Consensus Definitions for Sepsis and Septic Shock (Sepsis-3). JAMA. 2016;315:762-774.

20. Singer M, Deutschman CS, Seymour CW, Shankar-Hari M, Annane D, Bauer M, Bellomo R, Bernard GR, Chiche JD, Coopersmith CM, Hotchkiss RS, Levy MM, Marshall JC, Martin GS, Opal SM, Rubenfeld GD, van der Poll T, Vincent JL, Angus DC. The third international consensus definitions for sepsis and septic shock (Sepsis-3). JAMA 2016;315:801810.

21. Liu MW, Su MX, Wang YH, Wei W, Qin LF, Liu X, Tian ML, Qian CY. Effect of melilotus extract on lung injury by upregulating the expression of cannabinoid CB2 receptors in septic rats. BMC Complement Altern Med. 2014;14:94.

22. Ritter C, Andrades M, FrotaJúnior ML, Bonatto F, Pinho RA, Polydoro M, Klamt F, Pinheiro CT, Menna-Barreto SS, Moreira JC, Dal-Pizzol F. Oxidative parameters and mortality in sepsis induced by cecal ligation and perforation. Intensive Care Med. 2003;29:1782-1789.

23. Gregory SH, Barczynski LK, Wing EJ. Effector function of hepatocytes and Kupffer cells in the resolution of systemic bacterial infections. J Leukoc Biol. 1992;51:421-424.

24. Owen KA, Pixley FJ, Thomas KS, Vicente-Manzanares M, Ray BJ, Horwitz AF, Parsons JT, Beggs HE, Stanley ER, Bouton AH. Regulation of lamellipodial persistence, adhesion turnover, and motility in macrophages by focal adhesion kinase. J Cell Biol. 2007;179:1275-1287.

25. Moreno SE, Alves-Filho JC, Rios-Santos F, Silva JS, Ferreira SH, Cunha $F Q$, Teixeira MM. Signaling via platelet-activating factor receptors accounts for the impairment of neutrophil migration in polymicrobial sepsis. J Immunol. 2006;177:1264-1271.

26. Remick DG, Bolgos G, Copeland S, Siddiqui J. Role of interleukin-6 in mortality from and physiologic response to sepsis. Infect Immun. 2005;73:2751-2757.

27. Sherwood ER, Enoh VT, Murphey ED, Lin CY. Mice depleted of CD8+ $T$ and NK cells are resistant to injury caused by cecal ligation and puncture. Lab Invest. 2004;84:1655-1665.

28. Sedlak J, Lindsay RH. Estimation of total, protein-bound, and nonprotein sulfhydryl groups in tissue with Ellman's reagent. Anal Biochem. 1968;25:192-205.

29. Buege JA, Aust SD. Microsomal lipid peroxidation. Methods Enzymol. 1978;52:302-310.

30. Habig WH, Pabst MJ, Jakoby WB. Glutathione S-transferases. The first enzymatic step in mercapturic acid formation. J Biol Chem. 1974;249:7130-7139.

31. Benzie IF, Strain JJ. The ferric reducing ability of plasma (frap) as a measure of "antioxidant power: the frap assay. Anal Biochem. 1996;239:70-76.

32. Hillegass LM, Griswold DE, Brickson B, Albrightson-Winslow C. Assessment of myeloperoxidase activity in whole rat kidney. J Pharmacol Methods. 1990;24:285-295.

33. Malayeri MR, Dadkhah A, Fatemi F, Dini S, Torabi F, Tavajjoh MM, Rabiei J. Chemotherapeutic effect of Berberis integerrima hydroalcoholic extract on colon cancer development in the 1,2-dimethyl hydrazine rat model. Z Naturforsch C J Biosci. 2016;71:225-232.

34. Torabi F, Dadkhah A, Fatemi F, Dini S, Taghizadeh M, Mohammadi Malayeri MR. Prevention and therapy of 1,2-dimethyl hydrazine induced colon carcinogenesis by Ferula assafoetida hydroalcoholic extract. Turkish Journal of Biochemistry. 2015;40:390-400.

35. Angus DC, van der Poll T. Severe sepsis and septic shock. N Engl J Med. 2013;369:840-851.

36. Marshall JC. New translational research provides insights into liver dysfunction in sepsis. PLoS Med. 2012;9:1001341.

37. Alonso A, Misialek JR, Amiin MA, Hoogeveen RC, Chen LY, Agarwal SK, Loehr LR, Soliman EZ, Selvin E. Circulating levels of liver enzymes and 
incidence of atrial fibrillation: the Atherosclerosis Risk in Communities cohort. Heart. 2014;100:1511-1516.

38. Hubbard WJ, Choudhry M, Schwacha MG, Kerby JD, Rue LW 3rd, Bland KI, Chaudry IH. Cecal ligation and puncture. Shock. 2005;24(Suppl 1):52-57.

39. Toscano MG, Ganea D, Gamero AM. Cecal ligation puncture procedure. J Vis Exp. 2011.

40. Dadkhah A, Fatemi F, Alipour M, Ghaderi Z, Zolfaghari F, Razdan F. Protective effects of Iranian Achillea wilhelmsii essential oil on acetaminophen-induced oxidative stress in rat liver. Pharm Biol. 2015;53:220-227.

41. Villa P, Saccani A, Sica A, Ghezzi P. Glutathione protects mice from lethal sepsis by limiting inflammation and potentiating host defense. J Infect Dis. 2002;185;1115-1120.

42. Metzler KD, Fuchs TA, Nauseef WM, Reumaux D, Roesler J, Schulze I, Wahn V, Papayannopoulos V, Zychlinsky A. Myeloperoxidase is required for neutrophil extracellular trap formation: Implications for innate immunity. Blood. 2011;117:953-959.

43. Kothari N, Keshari RS, Bogra J, Kohli M, Abbas H, Malik A, Dikshit M, Barthwal MK. Increased myeloperoxidase enzyme activity in plasma is an indicator of inflammation and onset of sepsis. J Crit Care. 2011;26:435.

44. Konturek PC, Kania J, Burnat G, Hahn EG, Konturek SJ. Prostaglandins as mediators of COX-2 derived carcinogenesis in gastrointestinal tract. J Physiol Pharmacol. 2005;56(Suppl 5)57-73.

45. Samad TA, Sapirstein A, Woolf CJ. Prostanoids and pain: unraveling mechanisms and revealing therapeutic targets. Trends Mol Med. 2002;8:390-396.

46. Khan R, Sultana S. Farnesol attenuates 1,2-dimethylhydrazine induced oxidative stress, inflammation and apoptotic responses in the colon of Wistar rats. Chem-Biol Interact. 2011;192:193-200.

47. Rasooli A, Fatemi F, Hajihosseini R, Vaziria A, Akbarzadeh K, Mohammadi Malayerid MR, Dini S, Foroutanrad M. Synergistic effects of deuterium depleted water and Mentha longifolia L. essential oils on sepsis-induced liver injuries through regulation of cyclooxygenase-2.
Pharm Biol. 2019;57:125-132.

48. Kharpate S, Vadnerkar G, Jain D, Jain S. Evaluation of Hepatoprotective Activity of Ethanol Extract of Ptrospermum acerifolium Ster Leaves. Indian J Pharm Sci. 2007;69:850-852.

49. BarishevMG,DzhimakSS,Frolov VU,BolotinSN,DolgovMA. Technologies For Obtaining Deuterium Depleted Water. Membranes. 2013;3:523-526.

50. Basov AA, Elkina AA, Samkov AA, Volchenko NN, Moiseev AV, Fedulova LV, Baryshev MG, Dzhimak SS. Influence of Deuterium-Depleted Water on the Isotope D/H Composition of Liver Tissue and Morphological Development of Rats at Different Periods of Ontogenesis. Iran Biomed J. 2019; 23:129-41.

51. Doina PM, Olariu V, Scurtu M, Tulcan C, Brudiu I, Muntean D, Petcu F, Pădeanu I, Ostan M. The effect of deuterum depleted water on some hepatic enzymes' activity in rats intoxicated with chromium (VI). Fascicula: Ecotoxicologie, Zootehnie si Tehnologii de Industrie Alimentară. 2012:521-526.

52. Krempels K, Somlyai I, Somlyai G. A retrospective evaluation of the effects of deuterium depleted water consumption on 4 patients with brain metastases from lung cancer. Integr Cancer Ther. 2008;7:172-181.

53. Rašković A, Milanović I, Pavlović N, Cebović T, Vukmirović S, Mikov M. Antioxidant activity of rosemary (Rosmarinus officinalis L.) essential oil and its hepatoprotective potential. BMC Complement Altern Med. 2014;14:225.

54. Nithianantham K, Shyamala M, Chen Y, Latha LY, Jothy SL, Sasidharan S. Hepatoprotective potential of Clitoria ternatea leaf extract against paracetamol induced damage in mice. Molecules. 2011;16:10134-10145.

55. Lee HA, Koh EK, Sung JE, Kim JE, Song SH, Kim DS, Son HJ, Lee CY, Lee HS, Bae CJ, Hwang DY. Ethyl acetate extract from Asparagus cochinchinensis exerts anti-inflammatory effects in LPS-stimulated RAW264. 7 macrophage cells by regulating COX-2/iNOS, inflammatory cytokine expression, MAP kinase pathways, the cell cycle and antioxidant activity. Mol Med Rep. 2017;15:1613-1623. 